\title{
Determinants of Open Innovation and their Interrelations
}

\author{
Serhat Sağ $\breve{g}^{*, \hbar}$, Bülent Sezen*,§ and Lütfihak Alpkan ${ }^{\dagger, \pi}$ \\ *Gebze Technical University, Gebze, Turkey \\ $\dagger$ Istanbul Technical University, Istanbul, Turkey \\ $₫ s s a g @ g t u . e d u . t r$ \\ §ssezen@gtu.edu.tr \\ ॠalpkan@itu.edu.tr \\ Received 29 September 2017 \\ Accepted 23 April 2018 \\ Published 8 August 2018
}

\begin{abstract}
Based on an extensive literature review, this paper identifies nine erosion factors that lead to the birth of open innovation and discovers their interrelations by using Interpretive Structural Modeling (ISM). As a result, digital technologies and globalization emerged as major drivers. More interestingly, erosion factors proposed by leading open innovation scholars emerged as weak drivers, meaning that open innovation is driven by other factors. We argue that a better understanding of these factors and their interrelations provide valuable insights for managers and policy makers in emerging markets on facilitating the adoption of open innovation and promoting a more open business environment.
\end{abstract}

Keywords: Innovation; open innovation; Interpretive Structural Modeling (ISM); emerging economies.

\section{Introduction}

For much of the 20th century, corporate R\&D had been the dominant mode of innovation [West and Bogers (2014)]. However, during the 1990s business environment witnessed significant changes such as increasing competition, shortening product life-cycles, more demanding customers, accelerating speed of innovation. In response to these changes, firms adopted more open approaches to innovation instead of traditional vertical integrated model, or closed innovation as stated by Chesbrough [2003]. Open innovation is originally defined as "the use of purposive inflows and outflows of knowledge to accelerate internal innovation, and expand the markets for external use of innovation, respectively" [Chesbrough (2006)]. Due to the contributions of numerous academic studies and a more thorough understanding of open innovation paradigm, Chesbrough et al. [2014] proposed a novel definition: "a distributed innovation process based on purposively managed knowledge flows across organizational boundaries, using pecuniary and non-pecuniary mechanisms in line with each organization's business model".

\footnotetext{
\$Corresponding author.
} 
Since the introduction of open innovation to the literature, numerous academicians made contributions to develop and enhance understanding of the paradigm. Some academic studies argue that open innovation is a dynamic capability and carry open innovation into the domain of theories of firm strategy [Teece (2007); Chesbrough and Appleyard (2007); Rothaermel and Hess (2007)], while others focused on the relationship between open innovation and other main streams of research such as dynamic capabilities [Teece (2007)], resource-based view [Barney (1991)], absorptive capacity [Cohen and Levinthal (1990)], internal R\&D [Enkel et al. (2009)], intellectual property (IP) [Chesbrough and Ghafele (2014); Lichtenthaler (2010)], etc.

Some academics, on the other hand, brought complementary perspectives to open innovation such as "open distributed innovation" [von Hippel (2005)], "open source innovation" [Raasch et al. (2009)] and "open collaborative innovation" [Baldwin and von Hippel (2011)]. Some others criticized the paradigm as being an old wine in a new bottle [Trott and Hartmann (2009); Mowery (2009)]. However, open innovation is an umbrella term that encompasses, connects and integrates a range of already existing activities [Huizingh (2011)]. In addition, after the introduction of open innovation to the literature, the number of methods and tools used by firms to reach and in-source external knowledge and technologies grew and expanded. These recently popular methods include crowdsourcing [Howe (2006)], "innomediaries" (service firms that help companies innovate more effectively by connecting them over the internet with a wide variety of current and potential customers) [Sawhney et al. (2003); Weng (2017)], open innovation platforms such as P\&G's Connect and Develop, broadcast search [Lakhani (2006)], technology scouting [Rohrbeck (2010)], learning journeys [Ili et al. (2010)], etc.

While much of the early studies focused on open innovation practices in large enterprises (LEs) [Chesbrough (2006); Laursen and Salter (2006); Gassmann et al. (2010)], open innovation in small and medium enterprises (SME) also gained considerable attention [Van de Vrande et al. (2009); Lee et al. (2010); Ndou et al. (2011); Spithoven et al. (2013); Sağ et al. (2016)]. These studies focused on SMEs' successful open innovation practices [Vanhaverbeke (2017)] and also their motivation to adopt a more open approach. For instance, the main drivers for SMEs in adopting open innovation are fewer resources [Wynarczyk (2013)], low technological base [Vossen (1998)], lack of complementary assets required to commercialize internal innovation [Hemert et al. (2013)] and lack of skills to manage innovation process [Edwards et al. (2005)].

Since there exist a couple of successful open innovation examples in emerging economies [Motohashi (2014)], open innovation in developed versus emerging markets is still a less researched area [Chaston and Scott (2012)]. Existing studies, on the other hand, yield conflicting results. Some academic studies argue that only a few firms in emerging markets perceived the benefits of openness [Zou et al. (2010)] and only a few large and sophisticated companies adopted an open innovation approach [Ren et al. (2009)]. Wang and Zhou [2012], on the other hand, argue that open innovation is inapplicable to emerging countries due to the lack of strong technological capabilities and competencies. However, Torvinen and Väätänen [2015] found 
that companies in less developed economies are open in their innovation activities and give priority to external technology acquisition over internal R\&D due to resource and capability disadvantage.

In this context, we argue that the difference between developed and emerging countries in terms of open innovation is similar to the difference between LEs and SMEs. Related literature provides evidence that major disadvantages of SMEs over LEs are similar to disadvantages of firms in emerging economies over firms in developed economies. When compared to their counterparts in developed countries, firms in emerging markets lack skilled labour force [Feldens et al. (2012)], lack management skills to improve innovation processes [Karo and Kattel (2010)] and have fewer financial resources [Scott and Chaston (2013)]. Hence, we argue that firms in emerging markets can and should adopt a more open approach to innovation in order to reduce costs, learn new management skills to improve internal innovation processes and finally to develop new or improved products.

In addition to internal factors, external factors such as government programs, supporting infrastructure [Minshall et al. (2014)], regional innovation policies, incentive systems and IP protection mechanisms also influence firms' decision to be more open [Torvinen and Väätänen (2015)]. The effect of these societal and governmental factors is even stronger in emerging economies than in developed economies [Hoskisson et al. (2000)]. Therefore, we argue that managers and policy makers in emerging markets need to understand the determinants of open innovation and their interrelations to facilitate its adoption and promote a more open economy.

The aim of this paper is to discover complex relationships among factors that undermined the logic of closed innovation by using Interpretive Structural Modeling (ISM). The rest of this paper is as follows. First, we provide a brief description of erosion factors that we have identified. Then we explained ISM Methodology and its steps. Our arguments continues with the interpretation of resulting ISM Model. After discussions and conclusion section, which includes implications of this study for emerging economies, we conclude with limitations of the study and suggestions for further research.

\section{Determinants of Open Innovation}

In his seminal book, Chesbrough proposed four significant changes in business landscape that eroded closed innovation logic: the increasing availability and mobility of skilled workers, venture capital market, external options for ideas sitting on the shelf and increasing capability of external suppliers [Chesbrough (2003)]. Focusing solely on project-based R\&D collaborations, Pattit [2012] listed seven prominent environmental factors that indirectly influence the project-level R\&D outsourcing decision of companies and he argued that some of them have played a role in the erosion of the "closed innovation" paradigm. More recently, Chesbrough et al. [2014] added internet and the rise of social media as the fifth erosion factor.

Since the introduction of open innovation to the literature, numerous academic studies related to open innovation appeared in academic journals. Most of these highly cited studies focused on the positive effects of this contemporary approach to 
firms' innovative performance. However, to the best of our knowledge, only a few of them focused on identifying additional factors that eroded closed logic and led to the birth of open innovation. On the other hand, as pointed out by Chesbrough [2003] some of these factors are interrelated. But academic studies that analyzed the relationships between erosion factors are still missing in the literature. We argue that revealing interrelations between environmental factors that both pull and push firms to adopt open innovation will provide insight for managers and policy makers, particularly for those in emerging markets, to better understand today's business environment and take suitable actions in order to promote a more open environment. Based on an extensive literature review, we identified a total of nine erosion factors.

\subsection{Digital technologies}

Open innovation emphasizes cooperation, interaction [Zhang et al. (2017); Baldwin and von Hippel (2011)] and knowledge sharing with individuals or organizations [Ikhsan et al. (2004)] outside firm boundaries. Before 20th century, knowledge was analog and knowledge sharing was mainly dependent on the actual movement of people [Tapscott (1996)]. At the beginning of 21st century, digital text displaced print as the primary means of access to the knowledge [Cope and Kalantzis (2009); Wilder and Ferris (2006)]. However, firms' ability to interact and collaborate with external actors was still limited and costly. Improvements in digital technologies during the 1990s and beyond increased connectivity among people, organizations and nations [OECD Publishing (2002)] and lowered costs, time and other difficulties associated with collaboration efforts [Brynjolfsson and Hitt (2000)]. More recently, web 2.0 tools made it possible for individuals and organizations from all over the world to interact and collaborate in the process of innovation and value creation [Karakas (2009)].

\subsection{Globalization}

Academics argued that firms' migration toward open innovation has been driven by globalization [Huizingh (2011); Popa et al. (2017)], which is defined as the process of interaction and integration among people, companies and nations. Firms' increasing dependence on external sources of technology [Roberts (1995)] and the need to monitor and insource improvements beyond national boundaries [Bartlett and Ghoshal (1989); Howells and Wood (1993)] caused the globalization of innovation ecosystems [Castells (2011)]. Hence, Multinational Enterprises (MNEs) from developed economies have globalized their $\mathrm{R} \& \mathrm{D}$ activities and adopted a more open approach to source innovations from external actors, including those in emerging economies [Li and Kozhikode (2009)]. Therefore, globalization resulted in significant changes in business conditions especially in emerging markets. For instance, being opened to foreign competition from MNEs [Sun et al. (2018)] stimulated innovation [Gorodnichenko et al. (2010)]. Hence, firms in emerging markets moved from process to product focus and from imitation to innovation [Li and Kozhikode (2009)] in order to catch up with investing multinationals. At the same time, this trend gave them 
the opportunity to transfer the capability of MNEs through collaboration [Gorodnichenko et al. (2010)].

\subsection{Increasing availability and mobility of skilled workers [Chesbrough (2003)]}

During the second half of 20th century, U.S. dominated the skilled labor force market. Seventeen of the top 20 universities in the world were American and over half of all Science and Engineering $\mathrm{PhD}$ graduates were granted in U.S. However, after the 1990s, U.S. share in S\&E graduates declined sharply, while the number of $\mathrm{PhD}$ candidates enrolled in Chinese Universities increased six times [Freeman (2006)]. In addition to increasing availability of skilled workers, globalization made skilled workers more mobile and even more easily able to cross national borders [Liu et al. (2010)], which also plays an important role in knowledge diffusion across national borders [Saxenian (2007)].

\subsection{Venture capital (VC) market [Chesbrough (2003)]}

Availability of venture capital provides new opportunities for skilled workers. These individuals could be lured away to join new start-ups or they could find enough funding to start their own companies [Chesbrough (2003)]. In addition, venture capital firms, relatively recently introduced into emerging markets, contributes to the evolution of regional innovation ecosystem by fostering coevolution among interconnected players and through linkages between venture capital firms and MNEs [Sun et al. (2018)].

\subsection{External options for ideas sitting on the shelf [Chesbrough (2003)]}

In closed innovation era, ideas, knowledge and technologies used to sit on the shelf due to lack of complementary assets, lack of knowledge or lack of ability to evaluate their potential value. However, external pathways for internal innovation grew and expanded with the acceptance and adoption of open innovation approach. Today, open firms are actively searching external environment to benefit more from their internal efforts. For instance, they use innomediaries to find a partner for Joint $\mathrm{R} \& \mathrm{D}$, scout for external actors already having required complementary assets or market their patents to increase licensing revenues.

\subsection{Increasing capability of external suppliers [Chesbrough (2003)]}

Today, it is possible for firms to find offerings of equal or even superior quality to what could be achieved internally [Chesbrough (2003)]. Therefore, instead of performing every function in the value chain on their own, firms are more willing to outsource non-essential functions to external suppliers. In addition to outsourcing, open firms involve in deeper collaboration with their suppliers and even allow them to involve in innovation processes. Related literature shows that suppliers are the most preferred collaborators [Laursen and Salter (2006)] and their involvement in 
product development process yield great benefits such as shortened development cycle, decreased cost and increased quality [Henke and Zhang (2010)].

\subsection{Increasing knowledge intensity and complexity of scientific field}

Knowledge is a very critical organizational resource and unlike material assets, it increases with use [Davenport and Prusak (1998)]. In line with its rapid expansion since the 1990s, the complexity of scientific knowledge increased and today it became nearly impossible even for multinational large enterprises to keep control of or handle whole knowledge related to their area of expertise. Therefore, firms are increasingly relying on external knowledge and technologies in order to turn their ideas and internal efforts into innovative outcomes [Herstad et al. (2008)].

\subsection{Increased quality of academic research}

Since the beginning of 20th century, universities pursued extensive research collaboration with industry. However, university-industry collaboration was limited to couple of examples between leading U.S. universities and large enterprises. After the 1980s, introduction of policies and incentives [Mowery et al. (2001); Feldens et al. (2012)] as well as establishment of Technology Transfer Offices [Siegel et al. (2003)] accelerated the increase in the number of university-industry collaborations. For universities, broader and deeper collaborations with industry [Wallin et al. (2014)] resulted in more thorough understanding of needs, which consequently yielded the generation of more useful knowledge and technologies. For firms, increased quality of academic research triggered willingness to collaborate with universities [Guimón (2013)] even with those beyond national boundaries.

\subsection{Availability of up to date external scientific knowledge}

Before digital age, information was bounded by physical restrictions of printed texts, and access to information was limited by geographical boundaries [Wilder and Ferris (2006)]. But today, digital technologies offer easy access to up to date external scientific knowledge whenever and wherever needed [Karakas (2009)]. We argue that easy access to external knowledge and technologies is a significant factor that affects firms' decision to adopt a more open approach.

\section{ISM Methodology}

In this paper, we applied ISM methodology for identifying and analyzing the interrelations among the determinants of open innovation because ISM provides a framework for complex problems and gives decision makers a realistic picture of current situation and the variables involved [Sage (1977); Attri et al. (2013)]. It is a powerful technique and can be applied in various fields. In social sciences it is mainly used for imposing order and direction on the complexity of relationships among the variables. ISM is an interpretive method that aims to identify complex relationships among factors according to a group of experts' judgement. In this context, 
ISM assists to better understanding what is believed and to recognizing what is not known [Attri et al. (2013)]. ISM process starts with the identification of factors and their interrelations according to group judgment. Then an overall structure is extracted from the complex set of factors, and finally specific relationships among these factors are illustrated in a diagraph model [Singh et al. (2007)].

Based on an extensive litereture review as well as discussions with experts from academia and industry, we identified nine factors that led to the birth of open innovation. Then, we followed the steps involved in ISM to understand the complex cause and effect relationship among these factors. Following are the steps involved in the ISM methodology:

- Developing a structural self-interaction matrix (SSIM) of elements indicating pairwise relationship between factors.

- Developing a reachability matrix from the SSIM, and checking the matrix for transitivity. Transitivity of the contextual relation is a basic assumption in the ISM which states that if element $\mathrm{A}$ is related to $\mathrm{B}$ and $\mathrm{B}$ is related to $\mathrm{C}$, then $\mathrm{A}$ will be necessarily related to $\mathrm{C}$.

- Partitioning of reachability matrix into different levels.

- Drawing a directed graph (diagraph) and removing transitive links according to the relationships given in the reachability matrix.

- Converting the resultant diagraph into an ISM, by replacing element nodes with statements.

- Reviewing the ISM model to check for conceptual inconsistency and making the necessary modifications.

\subsection{Structural self-interaction matrix}

As suggested by ISM methodolgy [Sage (1977); Attri et al. (2013)], our 10-person judgment group involved in this step consitsts experts from both academia and industry (four and six respectively). And all experts are well conversant with open innovation approach. First, pairwise relationships between factors are decided according to the group judgment. Then, SSIM, illustrated in Table 1, is developed based on contextual relationships between factors. To express the complex

Table 1. Structural self-interaction matrix (SSIM).

\begin{tabular}{|c|c|c|c|c|c|c|c|c|c|c|}
\hline No. & Determinants of open innovation & 1 & 2 & 3 & 4 & 5 & 6 & 7 & 8 & 9 \\
\hline 1 & Digital technologies & & $\mathrm{X}$ & $\mathrm{V}$ & $\mathrm{O}$ & $\mathrm{V}$ & $\mathrm{V}$ & $\mathrm{X}$ & $\mathrm{X}$ & $\mathrm{V}$ \\
\hline 2 & Globalization & & & $\mathrm{V}$ & $\mathrm{V}$ & $\mathrm{V}$ & $\mathrm{X}$ & $\mathrm{X}$ & $\mathrm{X}$ & $\mathrm{V}$ \\
\hline 3 & Mobility of skilled workers & & & & $\mathrm{A}$ & $\mathrm{X}$ & $\mathrm{X}$ & $\mathrm{O}$ & $\mathrm{O}$ & A \\
\hline 4 & Venture capital market & & & & & $\mathrm{X}$ & $\mathrm{O}$ & $\mathrm{O}$ & $\mathrm{O}$ & $\mathrm{O}$ \\
\hline 5 & External options for ideas on the shelf & & & & & & $\mathrm{O}$ & $\mathrm{O}$ & $\mathrm{O}$ & $\mathrm{A}$ \\
\hline 6 & Increasing capability of external suppliers & & & & & & & $\mathrm{X}$ & $\mathrm{A}$ & A \\
\hline 7 & $\begin{array}{l}\text { Increased knowledge intensity and complexity of } \\
\text { scientific field }\end{array}$ & & & & & & & & $\mathrm{X}$ & $\mathrm{X}$ \\
\hline 8 & Increased quality of academic research & & & & & & & & & $\mathrm{X}$ \\
\hline 9 & Availability of up to date scientific knowledge & & & & & & & & & \\
\hline
\end{tabular}


relationships among factors, four symbols have been used to denote the direction of relationship between the factors $i$ and $j$ (where $i<j$ );

- V: Parameter $i$ will lead to parameter $j$.

- A: Parameter $j$ will lead to parameter $i$.

- X: Parameters $i$ and $j$ will lead to each other.

- O: Parameters $i$ and $j$ are unrelated.

\subsection{Reachability matrix}

The SSIM has been converted into a binary matrix, called the initial reachability matrix by substituting V, A, X, O by 1 and 0 . The substitution of 1 s and 0 s are as per the following rules:

- If the $(i, j)$ entry is $\mathrm{V}$, the $(i, j)$ entry in the reachability matrix becomes 1 and the $(j, i)$ entry becomes 0 .

- If the $(i, j)$ entry is A, the $(i, j)$ entry in the reachability matrix becomes 0 and the $(j, i)$ entry becomes 1 .

- If the $(i, j)$ entry is $\mathrm{X}$, the $(i, j)$ entry in the reachability matrix becomes 1 and the $(j, i)$ entry becomes 1 .

- If the $(i, j)$ entry is $\mathrm{O}$, the $(i, j)$ entry in the reachability matrix becomes 0 and the $(j, i)$ entry becomes 0 .

The final reachability matrix, shown in Table 2, is developed by adding the driving and dependence power to the initial reachabilitiy matrix. Here, the driving power of a factor is the total number of factors (including itself), which it may help to achieve and the dependence power is the total number of factors (including itself), which may help in achieving it.

\subsection{Level partitions}

First, the reachability and antecedent sets for each factor are derived from the final reachability matrix. The reachability set consists of the element itself and other

Table 2. Final reachability matrix.

\begin{tabular}{|c|c|c|c|c|c|c|c|c|c|c|c|}
\hline No & Determinants of open innovation & 1 & 2 & 3 & 4 & 5 & 6 & 7 & 8 & 9 & $\begin{array}{c}\text { Driving } \\
\text { power }\end{array}$ \\
\hline 1 & Digital technologies & 1 & 1 & 1 & 0 & 1 & 1 & 1 & 1 & 1 & 8 \\
\hline 2 & Globalization & 1 & 1 & 1 & 1 & 1 & 1 & 1 & 1 & 1 & 9 \\
\hline 3 & $\begin{array}{l}\text { Increasing availability and mobility of } \\
\text { skilled workers }\end{array}$ & 0 & 0 & 1 & 0 & 1 & 1 & 0 & 0 & 0 & 3 \\
\hline 4 & Venture capital market & 0 & 0 & 1 & 1 & 1 & 0 & 0 & 0 & 0 & 3 \\
\hline 5 & External options for ideas on the shelf & 0 & 0 & 1 & 1 & 1 & 0 & 0 & 0 & 0 & 3 \\
\hline 6 & Increasing capability of external suppliers & 0 & 0 & 1 & 0 & 0 & 1 & 1 & 0 & 0 & 3 \\
\hline 7 & $\begin{array}{l}\text { Increased knowledge and complexity of } \\
\text { scientific field }\end{array}$ & 1 & 0 & 0 & 0 & 0 & 1 & 1 & 1 & 1 & 5 \\
\hline 8 & Increased quality of academic research & 1 & 0 & 0 & 0 & 0 & 1 & 1 & 1 & 1 & 5 \\
\hline \multirow[t]{2}{*}{9} & $\begin{array}{l}\text { Availability of up to date scientific } \\
\text { knowledge }\end{array}$ & 0 & 0 & 1 & 1 & 1 & 1 & 1 & 1 & 1 & 7 \\
\hline & Dependence power & 4 & 2 & 7 & 4 & 6 & 7 & 6 & 5 & 5 & \\
\hline
\end{tabular}


elements which it may help achieve, whereas the antecedent set consists of the element itself and the other elements which may help achieving it. Then the intersection of these sets is derived for all elements. The elements for which the reachability and intersection sets are the same is the top-level element in the ISM hierarchy. The top-level element of the hierarchy would not help achieve any other element above its own. Once the top-level element of the hierarchy is identified, it is separated out from the other elements. Then by following the same process, the next level of elements is found. These identified levels help in building the diagraph and final model. In Table 3, it is shown that the "Increasing Mobility of Skilled Workers", "External Options for Ideas on the Shelf" and "Increasing Capability of External Suppliers" are found at level one. So it would be positioned at the top of ISM hierarchy. This iteration is repeated till the levels of each factor are found. The results of iterations are shown in Tables $3-6$.

\subsection{Classification of factors}

In this step, factors are classified into four clusters, autonomous variables, dependent variables, linkage variables and independent variables. For illustration, the factor 2

Table 3. Iteration 1.

\begin{tabular}{|c|c|c|c|c|}
\hline Factor & Reachability set & Antecedent set & Intersection set & Level \\
\hline 1 & $1,2,3,5,6,7,8,9$ & $1,2,7,8$ & $1,2,7,8$ & \\
\hline 2 & $1,2,3,4,5,6,7,8,9$ & 1,2 & 1,2 & \\
\hline 3 & $3,5,6$ & $1,2,3,4,5,6,9$ & $3,5,6$ & $\mathbf{I}$ \\
\hline 4 & $3,4,5$ & $2,4,5,9$ & 4,5 & \\
\hline 5 & $3,4,5$ & $1,2,3,4,5,9$ & $3,4,5$ & $\mathbf{I}$ \\
\hline 6 & $3,6,7$ & $1,2,3,6,7,8,9$ & $3,6,7$ & $\mathbf{I}$ \\
\hline 7 & $1,6,7,8,9$ & $1,2,6,7,8,9$ & $1,6,7,8,9$ & \\
\hline 8 & $1,6,7,8,9$ & $1,2,7,8,9$ & $1,7,8,9$ & \\
\hline 9 & $3,4,5,6,7,8,9$ & $1,2,7,8,9$ & $7,8,9$ & \\
\hline
\end{tabular}

Table 4. Iteration 2

\begin{tabular}{lllll}
\hline Factor & Reachability set & Antecedent set & Intersection set & Level \\
\hline 1 & $1,2,4,7,8,9$ & $1,2,7,8$ & $1,2,7,8$ & \\
2 & $1,2,4,7,8,9$ & 1,2 & 1,2 & \\
4 & $\mathbf{4}$ & $\mathbf{2}, \mathbf{4}, \mathbf{9}$ & $\mathbf{4}$ & II \\
7 & $\mathbf{1}, \mathbf{7}, \mathbf{8}, \mathbf{9}$ & $\mathbf{1}, \mathbf{2}, \mathbf{7}, \mathbf{8}, \mathbf{9}$ & $\mathbf{1}, \mathbf{7}, \mathbf{8}, \mathbf{9}$ & II \\
8 & $\mathbf{1}, \mathbf{7}, \mathbf{8}, \mathbf{9}$ & $\mathbf{1}, \mathbf{2}, \mathbf{7}, \mathbf{8}, \mathbf{9}$ & $\mathbf{1}, \mathbf{7}, \mathbf{8}, \mathbf{9}$ & II \\
9 & $4,7,8,9$ & $1,2,7,8,9$ & $7,8,9$ & \\
\hline
\end{tabular}

Table 5. Iteration 3

\begin{tabular}{lllll}
\hline Factor & Reachability set & Antecedent set & Intersection set & Level \\
\hline 1 & $1,2,9$ & 1,2 & 1,2 & \\
2 & $1,2,9$ & 1,2 & 1,2 & \\
9 & $\mathbf{9}$ & $\mathbf{1 , 2}, \mathbf{9}$ & $\mathbf{9}$ & III \\
\hline
\end{tabular}


Table 6. Iteration 4 .

\begin{tabular}{lcccc}
\hline Factor & Reachability set & Antecedent set & Intersection set & Level \\
\hline $\mathbf{1}$ & $\mathbf{1}, \mathbf{2}$ & $\mathbf{1 , 2}$ & $\mathbf{1 , 2}$ & IV \\
$\mathbf{2}$ & $\mathbf{1}, \mathbf{2}$ & $\mathbf{1 , 2}$ & $\mathbf{1 , 2}$ & IV \\
\hline
\end{tabular}

having a driving power of 9 and dependence of 2 is positioned at a place corresponding to driving power of 9 and dependency of 2. Similarly, all other factors considered in this study are positioned on different quadrants depending on their driving power and dependency. Resulting classification is shown in Fig. 1.

According to ISM Methodology, the first cluster consists of the "autonomous factors" that have weak driving power and weak dependence. These factors are relatively disconnected from the system with which they have only a few links, which may not be strong. In our final model, "venture capital market" emerged as an autonomous variable. The "dependent factors" having strong dependence but weak driving power constitute the second cluster and lie close to the top of ISM hierarchy. "Increasing mobility of skilled workers", "external options for ideas sitting on the shelf" and "increasing capability of external suppliers" emerged as dependent factors in our final model. It is interesting to note that all erosion factors initially proposed by Chesbrough [2003] emerged as dependent or autonomous factors, meaning that they are highly dependent on other factors such as globalization, digitalization and availability of up to date scientific knowledge.

Third cluster has the "linkage factors" that have strong driving power and strong dependence. In our model, "increased knowledge intensity and complexity of scientific field", "increased quality of scientific knowledge" and "availability of up to date scientific knowledge" stays in this cluster. Finally, fourth cluster includes the "independent factors" having strong driving power but weak dependence. Globalization and digitalization emerged as independent factors, thus they lie at the bottom level of the final ISM model.

\begin{tabular}{|c|c|c|c|c|c|c|c|c|c|c|c|}
\hline \multirow{12}{*}{ 文 } & \multirow{5}{*}{ 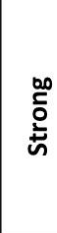 } & 9 & & 2 & & & & & & & \\
\hline & & 8 & & & & 1 & & & & & \\
\hline & & 7 & & & & & 9 & & & & \\
\hline & & 6 & & & & & & & & & \\
\hline & & 5 & & & & & 8 & 7 & & & \\
\hline & \multirow{7}{*}{ 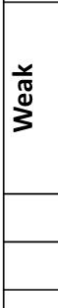 } & 4 & & & & & & & & & \\
\hline & & 3 & & & & 4 & & 5 & 3 & 6 & \\
\hline & & 2 & & & & & & & & & \\
\hline & & 1 & & & & & & & & & \\
\hline & & & 1 & 2 & 3 & 4 & 5 & 6 & 7 & 8 & 9 \\
\hline & & & \multicolumn{4}{|c|}{ Weak } & \multicolumn{5}{|c|}{ Strong } \\
\hline & & \multicolumn{10}{|c|}{ Dependence } \\
\hline
\end{tabular}

Fig. 1. Driving power and dependence diagram. 


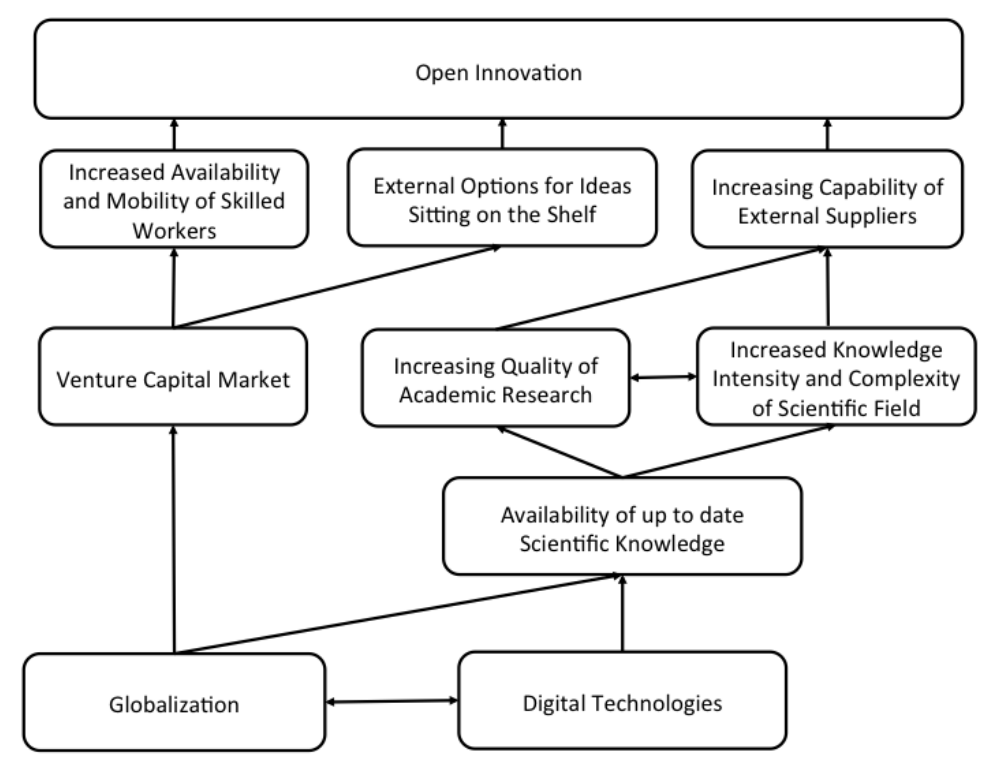

Fig. 2. ISM-based model.

\subsection{Formation of ISM-based model}

The structural model is generated by means of vertices or nodes and lines of edges from the final reachability matrix (Table 2 ). If there is a relationship between factors $i$ and $j$, this is shown by an arrow which points from $i$ to $j$. This graph is called a directed graph or diagraph. After removing transitivity, the diagraph is finally converted into ISM as shown in Fig. 2.

\section{Results}

The results of ISM, demonstrated in Fig. 2, indicate that digital technologies and globalization emerged as major drivers that led to the birth of open innovation approach. The interrelation between these two factors are illustrated by related literature. For instance, Arora et al. [2004] argued that globalization is driven by and is driving the new technology that enables global action. Consistently, other studies argued that improvements in digital technologies, particularly internet, has been a major driving force behind globalization [Lawlor (2007); Yip (2000); Karakas (2009)], while globalization triggers new advancements in information technologies and leverages digitalization.

According to our final ISM model, globalization and digitalization enabled availability of up to date scientific knowledge. Increased connectivity among people makes them feel as global citizens and participants of a virtual technology and knowledge platform [Stromquist (2002)]. Hence, anyone who is willing to create new knowledge can retrieve up to date information related to his/her area of research and build new ones on that knowledge [Castells (2011)]. Therefore, consistent with our final model, instant access to up to date knowledge increased knowledge intensity 
and complexity of scientific field [Chesbrough (2003)] as well as quality of academic research.

Furthermore, our final model indicates that availability of venture capital is directly influenced by globalization. Well-documented reports and surveys in literature illustrate that the results of our final ISM model are consistent. For instance, Kenney et al. [2004] provided evidence that international development agencies encouraged the formation of many of the early venture capital funds in emerging markets especially after the 1990s. US Agency for International Development funded a number of venture capital projects in Eastern Europe during early 1990s. On the other hand, a 2000 survey conducted by Japanese Ministry of Economy, Trade and Industry showed that the contribution of foreign investors increased by $26.3 \%$ between July 1999 and June 2000 [Ministry of Economy, Trade and Industry (2001)].

Moreover, our model shows that quality of academic research and increased knowledge intensity together have a direct effect on increasing capability of external suppliers, which subsequently effects firms' decision to outsource non-essential functions in order to focus on knowledge and technologies that provide competitive advantage. In addition, the availability of venture capital market, triggered by globalization, caused the increasing availability and mobility of skilled workers and also provided an opportunity to commercialize ideas, knowledge and technologies sitting on the shelf.

Finally, we noted that the factors initially proposed by Chesbrough [2003] increasing availability and mobility of skilled workers, external options for ideas sitting on the shelf and increasing capability of external suppliers - emerged at the top of hierarchy. In other words, these factors having relatively weak driving power are driven by other factors. Therefore, this study makes a significant contribution to open innovation literature by uncovering the antecedents of previously defined erosion factors.

\section{Discussions and Conclusion}

This paper provides a comprehensive model including direct and indirect effects of factors that undermined the logic of closed innovation and led to a more open business landscape. We believe that a better understanding of factors and their interrelations provide insight for a better understanding of current business environment, open innovation paradigm and also the near future of business environment. Considering the fact that firms in emerging economies are behind their counterparts in developed economies in terms of open innovation, findings of this study provide valuable insight particularly for managers and policy makers in emerging economies.

First of all, due to globalization and improvements in digital technologies [Lasi et al. (2014)] multinational enterprises from developed economies are increasingly globalizing their R\&D activities [Li and Kozhikode (2009)] and are regarding emerging markets as potential research and development locations [von Zedtwitz (2005a)]. However, this trend makes firms in emerging markets more vulnerable to increasing global competition both in local and foreign markets 
[Torvinen and Väätänen (2015); Sun et al. (2018)]. Therefore, policy makers in emerging economies are inherently unwilling to open their boundaries to foreign competition. However, cooperation in emerging economies enables firms to increase technological innovation [Pérez et al. (2018)] because it allows exchanges of skills. Recent studies show that emerging-market firms that open up their boundaries to foreign countries are more likely to benefit from external knowledge than others that are open to domestic organizations (see Kafouros and Forsans [2012] and Pai et al. [2012]). Hence, globalization provides opportunities for firms in emerging markets to tap into recent knowledge and technologies and to learn skills to manage open innovation related processes. Therefore, considering the results of this study along with supporting research, managers and policy makers need to refine strategic plans in a way that encourage and facilitate the use of knowledge from international markets [Pai et al. (2012)].

Furthermore, the existence of MNEs needs to be complemented by venture investments, which is vital in fostering a region's economic growth [Jeng and Wells (2000)]. Sun et al. [2018] found that a 1\% increase in the number venture capital leads to $3.7 \%$ increase in the number of patents. At firm level, a good record of patents is typically considered a quality measure, which can ensure the confidence of venture capitalists [Sun et al. (2018)]. However, at national level MNEs and VC count on legal stability [Gaur et al. (2018)], strong IP regime [Li and Kozhikode (2009)], well-structured institutional environment [Sun et al. (2018)] and transparency [Ahlstrom and Bruton (2006)]. Therefore, emerging markets are at a disadvantage compared to developed markets in expanding their venture capital markets. Da Rin et al. [2006] proposes three policy suggestions for emerging economies: offering an exit option with a large capital gain, tax incentives and fewer formalities to establish a corporation. We further suggest developing a more stable and transparent business environment supported by a well-structured institutional environment and a strong IP regime.

In addition, our final model illustrates that availability of venture capital market directly affects availability and mobility of skilled workers and provides external options for ideas sitting on the shelf. Samila and Sorenson [2011] found that availability of venture capital has a positive effect on the number of firm starts, employment and aggregate income. Analyzing the impact of returnees on improvement of regional and national innovative performance, Liu et al. [2010] found that returnees contribute to the regional improvement in emerging economies. However, these skilled workers can only be lured with the existence of enough Venture Capital. Therefore, consistent with our final model, Samila and Sorenson [2011] argue that when the supply of venture capital expands (1) entrepreneurs that anticipate a future need for financing are more likely start firms and (2) companies funded by venture capital are more likely to encourage employees to become entrepreneurs by enabling spinoffs. While the former argument illustrates the effect of venture capital on the mobility of skilled workers, the latter illustrates the increasing options for ideas sitting on the shelf. Another contribution of this study is the illustration of (1) venture capital market's critical role in facilitating the transformation from a closed 
approach to open innovation, (2) policies and incentives to increase its availability and finally (3) its contributions to national innovative performance.

Moreover, the results of this paper suggest that the inevitable trend of globalization needs to be supported by digitalization, which is defined as "the changes associated with the application of digital technology in all aspects of human society" [Stolterman and Fors (2004)]. Sabbagh et al. [2012] found that countries at the most advanced stage of digitization gain $20 \%$ more in economic benefits than those at the initial stage. At business or process level, on the other hand, costs can be cut by up to $90 \%$ by digitizing information intensive processes [Parviainen et al. (2017)]. However, analysis of socio-economic impact of ICT initiatives in India, an emerging economy, concluded that the usage of ICT was sparse in comparison with its potential [Chatterjee et al. (2007)]. In addition to reducing unemployment, improving quality of life, and boosting citizen access to public services, digitalization allows governments to operate with greater transparency [Sabbagh et al. (2012); Parviainen et al. (2017)]. Hence, digitalization helps emerging economies in overcoming problems associated with lack of transparency and indirectly contributes to MNEs and VC existence. Therefore, this paper provides valuable insight for managers and policy makers on the importance and priority of digital transformation at all levels: process, business and government.

Finally, the results of this study illustrate the importance of access to up to date scientific knowledge in knowledge generation and quality of academic studies. Knowledge, unlike other assets, increases with share [Davenport and Prusak (1998)]. Hence, increasing access to digital technologies and Internet, along with globalization, empowers exponential growth in global knowledge generation [Sabbagh et al. (2012)]. Therefore, globalization of emerging economies, supported with transformation towards an advanced stage of digitalization, will provide easy access to up to date scientific knowledge for everyone. Subsequent increase in quality of academic studies and knowledge intensity, therefore, make significant contribution to the capability of all actors, including external suppliers, which is the most important source in external knowledge acquisition [Laursen and Salter (2006)]. Finally, existence of more capable actors in an economy results in an increase in the number of collaborations and the level of openness, which is an inevitable trend in today's business conditions.

\section{Limitations of the Study and Recommendations for Future Studies}

Due to limited number of factors, this study has some limitations. First, determinants of open innovation are identified based on a literature review. There may be some factor(s) that doesn't exist in literature yet. Hence, more factors could be identified and added to this structural framework. Second, the interrelations between factors have been determined by a group judgment. Our judgment group consists both academicians and experts from industry. Since ideal group composition cannot be reached in any situation, different people or different compositions probably will yield different results. Finally, the result of this study is based on the personal judgement of experts and needs statistical validation. Structural Equation 
Modeling (SEM) has the capability of testing the validity of such hypothetical model [Attri et al. (2013)].

In addition, analyzing each factor's individual impact on openness is an interesting research area to dive in. For instance, we found that globalization and digital technologies are the main drivers of openness. However, their relative impacts are still not known. Impact of different factors could be determined by analysing the correlation between existing indexes (e.g. Globalization Index, Digitalization Index, Innovation Indexes, etc.) and openness. Therefore, this study calls for the development of an Open Innovation Index. Measuring national, regional and firm level of openness will provide a great opportunity for researchers to analyze how openness is related to globalization, digitalization or most importantly innovation.

\section{Special Issue Note}

An earlier version of this paper was presented at the 13th International Strategic Management Conference, organized by the International Strategic Management and Managers Association of Istanbul, Turkey, in collaboration with Istanbul Technical University, Gebze Technical University, Yildiz Technical University, and Mediterranean University Montenegro, on 6-8 July 2017, in Podgorica, Montenegro.

\section{References}

Ahlstrom, D. and Bruton, G. D. (2006). Venture capital in emerging economies: Networks and institutional change. Entrepreneurship Theory and Practice, 30, 2: 299-320.

Arora, A., Fosfuri, A. and Gambardella, A. (2004). Markets for Technology: The Economics of Innovation and Corporate Strategy. Cambridge, MA: MIT Press.

Attri, R., Dev, N. and Sharma, V. (2013). Interpretive structural modelling (ISM) approach: An overview. Research Journal of Management Sciences, 2319: 1171.

Baldwin, C. and von Hippel, E. (2011). Modeling a paradigm shift: From producer innovation to user and open collaborative innovation. Organization Science, 22, 6: 1399-1417.

Barney, J. (1991). Firm resources and sustained competitive advantage. Journal of Management, 17, 1: 99-120.

Bartlett, C. A. and Ghoshal, S. (1989). Managing across borders: The transnational solution. Boston, MA: Harvard Business School Press.

Brynjolfsson, E. and Hitt, L. M. (2000). Beyond computation: Information technology, organizational transformation and business performance. The Journal of Economic Perspectives, 14, 4: 23-48.

Castells, M. (2011). The rise of the network society: The information age. Economy, Society, and Culture, Vol. 1. John Wiley \& Sons. Malden, MA: Wiley-Blackwell, pp. 143-163.

Chaston, I. and Scott, G. J. (2012). Entrepreneurship and open innovation in an emerging economy. Management Decision, 50, 7: 1161-1177.

Chatterjee, J., Prabhakar, T. V. and Sarkar, R. (2007). Evolution of a digital ecosystem for knowledge services to Indian agriculture. Digital Business Ecosystems, European Commission. Information Society and Media.

Chesbrough, H. (2003). Open Innovation: The New Imperative for Creating and Profiting from Technology. Harvard Business School, Boston.

Chesbrough, H. W. (2006). Open Innovation: The New Imperative for Creating and Profiting from Technology. Boston, MA: Harvard Business School Press. 
Chesbrough, H. W. and Appleyard, M. M. (2007). Open innovation and strategy. California Management Review, 50, 1: 57-76.

Chesbrough, H., Vanhaverbeke, W. and West, J. (2014). New Frontiers in Open Innovation. OUP, Oxford.

Chesbrough, H. and Ghafele, R. (2014). Open innovation and intellectual property: A twosided market perspective, in New Frontiers in Open Innovation, Chesbrough, H., W. Vanhaverbeke, J. West (Eds.). Oxford: Oxford University Press, pp. 191-207.

Cohen, W. M. and Levinthal, D. (1990). Absorptive capacity: A new perspective on learning and innovation. Administrative Science Quarterly, 35, 128-152.

Cope, B. and Kalantzis, M. (2009). The role of the internet in changing knowledge ecologies. Arbor, 737, 521.

Da Rin, M., Nicodano, G. and Sembenelli, A. (2006). Public policy and the creation of active venture capital markets. Journal of Public Economics, 90, 8: 1699-1723.

Davenport, T. H. and Prusak, L. (1998). Working Knowledge: How Organizations Manage What They Know. Harvard Business Press.

Edwards, T., Delbridge, R. and Munday, M. (2005). Understanding innovation in small and medium-sized enterprises: A process manifest. Technovation, 25, 10: 1119-1127.

Enkel, E., Gassmann, O. and Chesbrough, H. (2009). Open R\&D and open innovation: Exploring the phenomenon. RED Management, 39, 4: 311-316.

Feldens, M., Maccari, E. and Garcez, M. (2012). Barriers for production innovation in small and medium technology-based firms in Brazil. Brazilian Business Review, 9, 3: 1-12.

Feldman, M. P., Link, A. N. and Siegel, D. (2012). The Economics of Science and Technology: An Overview of Initiatives to Foster Innovation, Entrepreneurship, and Economic Growth. Springer Science \& Business Media.

Freeman, R. B. (2006). Does globalization of the scientific/engineering workforce threaten US economic leadership? Innovation Policy and the Economy, 6: 123-157.

Gassmann, O., Enkel, E. and Chesbrough, H. (2010). The future of open innovation. RESD Management, 40, 3: 213-221.

Gaur, A. S., Ma, X. and Ding, Z. (2018). Home country supportiveness/unfavorableness and outward foreign direct investment from China. Journal of International Business Studies, 49, 3: 324-345.

Gorodnichenko, Y., Svejnar, J. and Terrell, K. (2010). Globalization and innovation in emerging markets. American Economic Journal: Macroeconomics, 2, 2: 194-226.

Guimón, J. (2013). Promoting university-industry collaboration in developing countries. Policy brief. The Innovation Policy Platform, 1, 3: 1-12.

Hemert, P., Nijkamp, P. and Masurel, E. (2013). From innovation to commercialization through networks and agglomerations: Analysis of sources of innovation, innovation capabilities and performance of Dutch SMEs. The Annals of Regional Science, 50, 2: $425-452$.

Henke, J. W. and Zhang, C. (2010). Increasing supplier-driven innovation. MIT Sloan Management Review, 51, 2: 41.

Herstad, S. J., Bloch, C., Ebersberger, B. and van de Velde, E. (2008). Open Innovation and Globalisation: Theory, Evidence and Implications. VISION Eranet, Helsinki.

Hoskisson, R. E., Eden, L., Lau, C. M. and Wright, M. (2000). Strategy in emerging economies. Academy of Management Journal, 43, 3: 249-267.

Howe, J. (2006). The rise of crowdsourcing. Wired Magazine, 14, 6: 1-4.

Howells, J. and Wood, M. (1991). The globalisation of production and technology. Brussels: FAST, Commission of the European Communities, Science, Research and Development.

Huizingh, E. K. (2011). Open innovation: State of the art and future perspectives. Technovation, 31, 1: 2-9.

Ili, S., Albers, A. and Miller, S. (2010). Open innovation in the automotive industry. RESD Management, 40, 3: 246-255. 
Ikhsan, S., Sharifuddin, S. O. and Rowland, F. (2004). Knowledge management in a public organisation in Malaysia: Do people really share? Available from http://repo.uum.edu. my/13829/1/KM86.pdf.

Jeng, L. A. and Wells, P. C. (2000). The determinants of venture capital funding: Evidence across countries. Journal of corporate Finance, 6, 3: 241-289.

Kafouros, M. I. and Forsans, N. (2012). The role of open innovation in emerging economies: Do companies profit from the scientific knowledge of others. Journal of World Business, 47, 3: 362-370.

Karakas, F. (2009). Welcome to World 2.0: The new digital ecosystem. Journal of Business Strategy, 30, 4: 23-30.

Karo, E. and Kattel, R. (2010). Coordination of innovation policies in the catching-up context: A historical perspective on Estonia and Brazil. International Journal of Technological Learning, Innovation and Development, 3, 4: 293-329.

Kenney, M., Han, K. and Tanaka, S. (2004). The globalization of venture capital: The cases of Taiwan and Japan. Financial Systems, Corporate Investment in Innovation, and Venture Capital, Bartzokas, A., and Mani, S. (Eds.). Cheltenham, UK: Edward Elgar, pp. 52-84.

Lakhani, K. R. (2006). Broadcast search in problem solving: Attracting solutions from the periphery. In Technology Management for the Global Future, 2006. PICMET 2006, Vol. 6, pp. 2450-2468, IEEE.

Lasi, H., Fettke, P., Kemper, H. G., Feld, T. and Hoffmann, M. (2014). Industry 4.0. Business E Information Systems Engineering, 6, 4: 239-242.

Laursen, K. and Salter, A. (2006). Open for innovation: The role of openness in explaining innovation performance among UK manufacturing firms. Strategic Management Journal, 27, 2: 131-150.

Lawlor, B. (2007). The age of globalization: Impact of information technology on global business strategies. Available from Digital Commons at BryantUniversity: http://digitalcommons.bryant.edu/cgi/viewcontent.cgi?article=1000\&context=honors_cis.

Lee, S., Park, G., Yoon, B. and Park, J. (2010). Open innovation in SMEs - An intermediated network model. Research Policy, 39, 2: 290-300.

Li, J. and Kozhikode, R. K. (2009). Developing new innovation models: Shifts in the innovation landscapes in emerging economies and implications for global R\&D management. Journal of International Management, 15, 3: 328-339.

Lichtenthaler, U. (2010). Intellectual property and open innovation: An empirical analysis. International Journal of Technology Management, 52, 3/4: 372-391.

Liu, X., Wright, M., Filatotchev, I., Dai, O. and Lu, J. (2010). Human mobility and international knowledge spillovers: Evidence from high-tech small and medium enterprises in an emerging market. Strategic Entrepreneurship Journal, 4, 4: 340-355.

Ministry of Economy, Trade and Industry (METI of Japan) (2001), Annual Survey of Japanese Venture Capital Investments, prepared by Venture Enterprise Center (VEC), Tokyo: VEC.

Minshall, T., Kouris, S., Mortara, L., Schmithausen, P. and Weiss, D. (2014). Developing infrastructure to support open innovation: Case studies from the east of England. International Journal of Innovation and Technology Management, 11, 1: 1440006.

Motohashi, K. (2014). Multinational's global open innovation activities in emerging markets: A case of Japanese firms' collaborations with national research institutes in Thailand. Available from http://mpra.ub.uni-muenchen.de/56187/

Mowery, D. C., Nelson, R. R., Sampat, B. N. and Ziedonis, A. A. (2001). The growth of patenting and licensing by US universities: An assessment of the effects of the Bayh-Dole act of 1980. Research Policy, 30, 1: 99-119.

Mowery, D. C. (2009). Plus ca change: Industrial R\&D in the "third industrial revolution". Industrial and Corporate Change, 18, 1: 1-50.

Ndou, V., Vecchio, P. D. and Schina, L. (2011). Open Innovation Networks: The role of innovative marketplaces for small and medium enterprises' value creation. International Journal of Innovation and Technology Management, 8, 3: 437-453. 
OECD Publishing (2002). OECD Science, Technology and Industry Outlook 2002.

Pai, D. C., Tseng, C. Y. and Liou, C. H. (2012). Collaborative innovation in emerging economies: Case of India and China. Innovation, 14, 3: 467-476.

Parviainen, P., Tihinen, M., Kääriäinen, J. and Teppola, S. (2017). Tackling the digitalization challenge: How to benefit from digitalization in practice. International Journal of Information Systems and Project Management, 5, 1: 63-77.

Pattit, J. M. (2012). The R\&D Boundaries of the Firm and the Governance of R\&D Alliances: Essays on Institutions, Strategic Considerations and Contract Structure. Dissertation, Syracuse University.

Pérez, J. A. H., Geldes, C., Kunc, M. H. and Flores, A. (2018). New approach to the innovation process in emerging economies: The manufacturing sector case in Chile and Peru. Technovation.

Popa, S., Soto-Acosta, P. and Martinez-Conesa, I. (2017). Antecedents, moderators, and outcomes of innovation climate and open innovation: An empirical study in SMEs. Technological Forecasting and Social Change, 118: 134-142.

Raasch, C., Herstatt, C. and Balka, K. (2009). On the open design of tangible goods. RED Management, 39, 4: 382-393.

Ren, L., Xie, G. and Krabbendam, K. (2009). Sustainable competitive advantage and marketing innovation within firms: A pragmatic approach for Chinese firms. Management Research Review, 33, 1: 79-89.

Roberts, E. B. (1995). Benchmarking the strategic management of technology - I. ResearchTechnology Management, 38, 1: 44-56.

Rohrbeck, R. (2010). Harnessing a network of experts for competitive advantage: Technology scouting in the ICT industry. RED Management, 40, 2: 169-180.

Rothaermel, F. T. and Hess, A. M. (2007). Building dynamic capabilities: Innovation driven by individual-, firm-, and network-level effects. Organization Science, 18, 6: 898-921.

Sabbagh, K., Friedrich, R., El-Darwiche, B., Singh, M., Ganediwalla, S. and Katz, R. (2012). Maximizing the impact of digitization. The global information technology report, pp. $121-133$.

Sage, A. P. (1977). Systems Engineering: Methodology $\&$ Applications. IEEE Computer Society Press. New York, New York.

Sağ, S., Sezen, B. and Güzel, M. (2016). Factors that motivate or prevent adoption of open innovation by smes in developing countries and policy suggestions. Procedia-Social and Behavioral Sciences, 235: 756-763.

Samila, S. and Sorenson, O. (2011). Venture capital, entrepreneurship, and economic growth. The Review of Economics and Statistics, 93, 1: 338-349.

Sawhney, M., Prandelli, E. and Verona, G. (2003). The power of innomediation. MIT Sloan Management Review, 44, 2: 77.

Saxenian, A. (2007). The new argonauts: Regional advantage in a global economy. Harvard University Press. pp. 99-110.

Scott, G. and Chaston, I. (2013). Open innovation in an emerging economy. Management Research Review, 36, 10: 1024-1036.

Siegel, D. S., Waldman, D. A., Atwater, L. E. and Link, A. N. (2003). Commercial knowledge transfers from universities to firms: Improving the effectiveness of university-industry collaboration. The Journal of High Technology Management Research, 14, 1: 111-133.

Singh, R. K., Garg, S. K., Deshmukh, S. G. and Kumar, M. (2007). Modelling of critical success factors for implementation of AMTs. Journal of Modelling in Management, 2, 3: 232-250.

Spithoven, A., Vanhaverbeke, W. and Roijakkers, N. (2013). Open innovation practices in SMEs and large enterprises. Small Business Economics, 41, 3: 537-562.

Stolterman, E. and Fors, A. C. (2004). Information technology and the good life. Information Systems Research. Springer, Boston, MA, pp. 687-692. 
Stromquist, N. P. (2002). Education in a Globalized World: The Connectivity of Economic Power, Technology, and Knowledge. Rowman \& Littlefield Publishers.

Sun, S. L., Chen, V. Z., Sunny, S. A. and Chen, J. (2018). Venture capital as an innovation ecosystem engineer in an emerging market. International Business Review.

Tapscott, D. (1996). The Digital Economy: Promise and Peril in the Age of Networked Intelligence, Vol. 1. McGraw-Hill, New York.

Teece, D. J. (2007). Explicating dynamic capabilities: The nature and microfoundations of (sustainable) enterprise performance. Strategic Management Journal, 28, 13: $1319-1350$.

Torvinen, P. and Väätänen, J. (2015). Technology management strategies in emerging markets. In ISPIM Conference Proceedings (p. 1). The International Society for Professional Innovation Management (ISPIM).

Trott, P. and Hartmann, D. A. P. (2009). Why 'open innovation' is old wine in new bottles. International Journal of Innovation Management, 13, 4: 715-736.

Van de Vrande, V., De Jong, J. P., Vanhaverbeke, W. and De Rochemont, M. (2009). Open innovation in SMEs: Trends, motives and management challenges. Technovation, 29, 6: 423-437.

Vanhaverbeke, W. (2017). Managing Open Innovation in SMEs. Cambridge University Press.

Vossen, R.W. (1998). Research Note-Relative strengths and weaknesses of small firms in innovation. İnternational Small Business Journal, 16, 3: 88-94.

von Hippel, E. (2005). Democratizing innovation: The evolving phenomenon of user innovation. Journal für Betriebswirtschaft, 55, 1: 63-78.

von Zedtwitz, M. (2005a). International R\&D Strategies in Companies from Developing Countries: The Case of China. UN.

von Zedtwitz, M. (2005b). The evolution of research on R\&D and technology management in China.

Wallin, J., Isaksson, O., Larsson, A. and Elfström, B. O. (2014). Bridging the gap between university and industry: Three mechanisms for innovation efficiency. International Journal of Innovation and Technology Management, 11, 1: 1440005.

Wang, Y. and Zhou, Z. (2012). Can open innovation approach be applied by latecomer firms in emerging countries? Journal of Knowledge-based Innovation in China, 4, 3: $163-173$.

Weng, C. S. (2017). Innovation intermediaries in technological alliances. International Journal of Innovation and Technology Management, 14, 2: 1740013.

West, J. and Bogers, M. (2014). Leveraging external sources of innovation: A review of research on open innovation. Journal of Product Innovation Management, 31, 4: 814831.

Wilder, H. and Ferris, S. P. (2006). Communication technology and the evolution of knowledge. Journal of Electronic Publishing, 9, 2.

Wynarczyk, P. (2013). Open innovation in SMEs: A dynamic approach to modern entrepreneurship in the twenty-first characteristics, network openness and network information. International Journal of Technology Management, 62, 2: 223-250.

Yip, G. S. (2000). Global strategy in the Internet era. Business Strategy Review, 11, 4: 1-14.

Zhang, N., Zhao, X., Zhang, Z., Meng, Q. and Tan, H. (2017). What factors drive open innovation in China's public sector? A case study of official document exchange via microblogging (ODEM) in Haining. Government Information Quarterly, 34, 1: 126-133.

Zou, H., Chen, X. and Ghauri, P. (2010). Antecedents and consequences of new venture growth strategy: An empirical study in China. Asia Pacific Journal of Management, 27, 3: 393-421. 


\section{Biography}

Serhat Să is a $\mathrm{PhD}$ candidate at Gebze Technical University, Turkey. He completed his master's degree at University of California Berkeley, Industrial Engineering and Operations Research Department in 2009. His current research interests are open innovation, strategic management, external knowledge, innovation and technology management.

Bülent Sezen is a professor of Operations Management at Gebze Technical University. He obtained his $\mathrm{PhD}$ in Operations Management from Gebze Technical University in 2001. His research interests focus on lean production, logistics, inventory management, innovation management and supply chain management. His research studies have been published in several international journals including Journal of Business Research, Industrial Marketing Management, Production Planning and Control, Total Quality Management, International Journal of Business and Industrial Marketing, Expert Systems with Application, Supply Chain Management, and in numerous Turkish-language scholarly journals.

Lütfihak Alpkan is a professor of Management Engineering at Istanbul Technical University in Turkey. He obtained his PhD degree from Gebze Technical University in Management in 2000. He served as the head of the Social Sciences Institute (20062014) in Gebze Technical University. He joined Istanbul Technical University at the end of 2014. His current research interests include Strategic Management, Innovation Management, Entrepreneurship, and Business Ethics. He has more than 50 papers published in top ISI Journals. He is vice president of an association, chairman and co-chairman of two international conferences and co-editor of a journal. 